\title{
The Americanisation of the European business system?
}

\section{Ian Clark, Philip Almond, Patrick Gunnigle and Hartmut Wachter}

\begin{abstract}
This article examines the impact of contemporary business practices within the American business system on established patterns of industrial relations (IR) management in European subsidiaries of US multinationals, specifically how established firm-level settlements for the management of IR may or may not combine with host-country effects to constrain such innovations. The empirical material leads us to evaluate subsidiaries of US multinationals as a contingent factor indicating that institutional effects at the level of the national business system are likely to be more embedded than the effects of ownership on employment and IR at firm level.
\end{abstract}

\section{INTRODUCTION}

In our contribution to last year's review we sought to examine the impact of contemporary business practices within the American business system (ABS) on established patterns of industrial relations (IR) management in British subsidiaries of US multinational corporations (MNCs), specifically how established firm-level settlements for IR management may or may not combine with host-country effects to constrain such innovations (Clark and Almond, 2004). This year we seek to examine this argument on a more pan-European basis by comparing and contrasting our arguments and findings with those of our colleagues in Ireland and Germany. In so doing we present our material on two levels, first, at the level of the European business system (EBS) and second, at the level of the firm. This approach enables us to examine the extent to which the EBS must react to the growing pressures of internationalisation that might force it towards a more Americanised approach to IR management.

We were prompted to examine this issue in the light of some of the contributions to last year's review that evaluate what the EBS is for while suggesting that its restructuring and reinvigoration is leading the European model to converge on the American model (Edwards, 2004; Grahl and Teague, 2004; Jones and Bacon, 2004). This is important because the institutionalist literature drawn on by these contributors

$\square$ Ian Clark is Reader in Industrial Relations at the University of Kent, Philip Almond is Lecturer in the Centre for Labour Market Studies at the University of Leicester, Professor Patrick Gunnigle is Director of the Employment Research Unit at the University of Limerick, Ireland, and Hartmut Wachter is Professor of Business Management at the University of Trier, Germany. Correspondence should be addressed to Dr Ian Clark, Kent Business School, University of Kent, Canterbury, Kent CT2 7PE, UK; email: i.a.f.clark@kent.ac.uk 
and other commentators, for example, Gospel and Pendleton (2003) and Hutton (2002), emphasises the social embeddedness of national business systems and associated market institutions (in some cases supported by empirical material). This argument suggests that while the EBS retains much integrity it is in some ways acceding to internationalised pressures for change originating in the ABS. However, at a less abstract more grounded level some of our empirical material suggests that a tendency towards more contemporary aspects of Americanisation (downsizing, more determined short-termism and a less restrained pursuit of shareholder value), may be evident in the management of IR in European subsidiaries of US MNCs. More significantly, however, it may be the case that Americanisation is more evident in the management of managers particularly in the German business system. This assertion leads us in our empirical contribution to evaluate the presence of subsidiaries of US MNCs as a contingent factor that indicates why it is necessary to underpin the EBS and its associated social model. This is the case because broad institutional effects at the level of the national business system are likely to be more embedded than the effects of ownership on employment and IR at firm level, however, without recognising this the EBS may be in danger of being undermined by the spillover effects of US MNCs from the bottom-up. This spillover is evident in the apparent efficiency effects of US MNCs, for example, centralised, formalised and standardised approaches to IR management which become best practice templates for indigenous firms. Here the country-of-origin effect associated with US MNCs represents not only innovation in host nations but also is an 'efficiency' threat to more established and equitable patterns of IR therein. That is, country-of-origin effects are contingent on the overall institutional setting in a host country.

Theoretically, a tendency towards Americanisation across the EBS is dependent on several transfer mechanisms but as we suggest not all of these are necessarily grounded in the contemporary activities of US MNCs. DiMaggio and Powell (1983) identify three institutional transfer mechanisms: coercive, mimetic and normative. Coercive mechanisms dictate that management in indigenous firms in a particular sector must compare their performance against subsidiaries of US MNCs and these comparisons may lead to mimetic pressures to directly copy their practices or benchmark against them. In addition to this, normative transfer mechanisms also relate to contemporary best practice whereby practices associated with US MNCs may become part of management rhetoric, for example, the importance of cost containment and shareholder value. More subtly the emergent process of institutional isomorphism entails the assumed presence of structural and organisational equivalence whereby the adoption of similar practices (coercion, mimetics to best practice) at the level of the firm or a sector in the EBS may achieve similar results to those found in the ABS. However, these firm-level pressures exist separately from competitive isomorphism at the level of the system which necessarily assumes the presence of more market-orientated competition - the tendency towards Americanisation. This is the case because the nature of the mix between institutional isomorphism (firm-level change management) and competitive isomorphism (system-level change) has a significant impact on the nature of the transfer process, its speed and the scope of adaptation in the host model - the EBS. Therein local isomorphic factors such as European Union (EU) Directives are significant in shaping IR practices that may be at odds with features of the ABS that now appear as emergent best practice more globally, for example, the market for corporate control and variable pay for senior managers linked to share price performance. As we argue while the pressures for competitive isomorphism are 
undeniable the perceived necessity of more market-orientated competition in the EBS is problematic for two reasons, first as managerial rhetoric or even a catch-all term for change it may be ahead of the empirical findings and second, it assumes that by becoming more Americanised the EBS can more effectively compete with the ABS. (The recent rejection of the EU Constitution by French and Dutch voters in part demonstrates this point.) While this may or may not be the case, the implication of this second argument is that more radical adjustments are the most likely outcome whereas empirical studies confirm this in some sectors (e.g. Royle, 2004) multi-sector studies are more able to assess the pace and level of diffusion of contemporary business and IR practices associated with the ABS. Following on from these introductory arguments The Americanisation of the EBS examines the Americanisation of the EBS as competitive isomorphism whereas Americanisation, Europeanisation and firmlevel IR systems draws on pan-European material to evaluate the extent of institutional isomorphism in firm-level IR systems. This part of the article questions the extent to which coercive and mimetic pressures may actually result in normative pressures at the level of the system that move towards the competitive adoption of shareholder value approaches and the attendant 'downsize and distribute' model emphasised by O'Sullivan (2000). Americanisation or Europeanisation? Change, innovation and internationalisation in EBSs discusses the issues of innovation and internationalisation in the EBS in a more critical light and is followed by our conclusions.

\section{THE AMERICANISATION OF THE EBS}

In their editorial contribution to last year's review the editors posed the question of what the EU and the process of Europeanisation is actually for, rhetorically they suggest that the emergence of a fledgling EBS is essential to prevent the Balkanisation of national interpretations of the European model. Highlighting the Lisbon strategy that aims to see the EU become the world's leading 'knowledge economy' by 2010 Jones and Bacon (2004) imply that the promotion of lifelong learning and high-quality jobs aims to improve the performance of flawed national economies within the EU as well as controlling the less restrained activities of MNCs.

The question that follows on from this answer centres on the capability of the fledgling EBS to deliver on the Lisbon strategy and unify divergent political permissiveness in national economies towards MNCs, US MNCs in particular. For as Edwards (2004: 533) argues the process of restructuring and reinvigoration within the EBS demonstrates the tendency towards competitive isomorphism as Europe converges on Anglo-American approaches. Citing Lane (2003) Edwards highlights the diffusion of competitive pressures that witness the changing nature of stakeholder interests in the German economy whereby the growth of small- to medium-sized enterprises (SMEs) (the Mittelstand sector), foreign institutional investment and the rhetoric of shareholder value appear to be changing the nature of stakeholder interests towards the short-term imperative. Here the systematic constraints within the German business system around which the EBS is modelled appear to be weakened by the introduction of Anglo-American-type incentives for management particularly in SMEs. These arguments are similar to those of Jacoby (2000) who explicitly concludes that coordinated market economies in Europe are converging towards the more liberal market-orientated American model. Similarly, while a third contribution to last year's review suggests that the European elite are losing faith in the German and European model (Grahl and Teague, 2004: 561) it remains an open question as to whether the 
pattern of competitive pathway adjustment in the EBS will arrive at a more homogenous pattern of IR and work organisation be it tending towards Americanisation or a more determinedly European approach akin to the Lisbon strategy that emphasises employability through lifelong learning and development and a consequent modernisation of work organisation via national action plans.

\section{Americanisation vs. Europeanisation}

At the abstract level industrial capitalism is a system of economic rationality that assumes the unrestrained presence of private property, the market mechanism and associated price signals and free contracting incentivised by the efficiency bias of profit maximisation. However, industrial capitalism is grounded by the reality of historically derived national patterns of capitalism and attendant national business systems. National business systems have a pattern of institutional grounding in financial systems, legal systems, IR systems, patterns of contractual regulation and national culture, all of which contribute to the institutional relationship between stakeholders such as capital, labour and the state.

In the contemporary period two models of industrial organisation predominate, the ABS centred on market-led institutions - the liberal market economy-perhaps closer to the abstract model outlined above and the European model that emphasises more coordination within and between institutions - the coordinated market economy, each with its own associated social model of the economy and society (Hall and Soskice, 2001: Chapter 1). Critics of American capitalism and the ABS see the USA as a hegemonic 'hyper power' (Hutton, 2002: Chapter 1; Vedrine and Moisi, 2001). Now unrestrained by the previous edicts of the Cold War American dominance, its priorities, interests and values permeate and impact on and become part of other economic and social models such as in the apparent endemic tendency towards competitive isomorphism, leading some to argue that the Lisbon strategy aims not to arrest Americanisation but to promote it (Hutton, 2002: 15). A complicating factor in this tendency is that the EBS encompasses a continent and not a country, wherein individual nation states guard, protect, amend and change embedded values and associated institutional infrastructures and associated social models on the basis of a variety of national interests. Coercive, mimetic and normative transmission mechanisms associated with the diffusion of US MNCs or the fledgling EBS are unlikely to converge on a centrally determined European approach or one premised on the economic advantages associated with the ABS. Hence, functionalist arguments that emphasise the competitive isomorphic tendency towards Americanisation (or Europeanisation) are less than satisfactory (see Whitley, 2000: 114). Our empirical material detailed in the next part of the article suggests that while some institutional isomorphism may be in evidence across national varieties of capitalism within the EU, the degree of managerial permissiveness therein is evidence of differences between national varieties. Equally, the ABS while market-orientated is equally permissive in approaches to IR at the level of the firm.

\section{AMERICANISATION, EUROPEANISATION AND FIRM-LEVEL IR SYSTEMS}

As we suggested last year the relationship between macro-level pressures such as internationalisation, reform and restructuring in business systems and the 
relationship of these to changes and developments in firm-level IR settlements is not a direct process of transmission but on that must take account of socially embedded market institutions therein. The discussion and evaluation of Americanisation and its more immediate manifestation in the emergence of shareholder value approaches to corporate governance is problematic precisely because much of this discussion is couched in general analysis of pressures on systems that are likely to result in some discernible pressures on job regulation at the level of the firm. As we have previously argued, any assessment of shareholder value and associated developments in corporate governance and IR at the level of the firm must recognise that the term is loosely even vaguely defined, is imprecise and more recently openly contested. For example, Caterpillar, the world's largest manufacturer of construction equipment, has recently faced a shareholder challenge fronted by trade union pension funds who aim to ensure that Directors are appointed only on the basis of majority voting. More significantly than the challenge is the fact that it supported by Institutional Shareholder Services and Glass Lewis, two influential US voting agencies more usually associated with the pursuit of shareholder returns than the interests of special-interest groups such as trade unions and pension funds (Tucker, 2005). In contrast to this case in Germany Daimler Chrysler's largest shareholder Deutsche Bank has openly criticised the poor value and performance of the company, in particular its lack of strategy and more open short-termism (Milne, 2005). Technological convergence and associated market pressures to contain costs are assumed by convergence theorists to stimulate a convergence of organisational structures within MNCs whereby centrally determined operational targets assume the character of those found in US MNCs. Such 'coercive comparisons' are easy to cite yet the literature suggests that they are likely to be 'sectorspecific' rather than 'system-generalisable'; for example, Royle (2004) reports that the entry of American quick food retailers in Germany and Spain has led to the Americanisation (greater product standardisation, use of non-union labour, lower pay and lower trust relations) of those sectors in these business systems. Furthermore, Coller and Marginson (1998) argue that coercive and mimetic benchmarking within MNCs is used to identify best practice internally not externally across a particular sector. Nonetheless, as a competitive generalisation the emergence of shareholder value approaches tighten the reins of corporate centralisation, inevitably leading to a reduction in subsidiary autonomy. It follows from this that the country-of-origin effect whereby US MNCs seek to diffuse practices associated with the ABS into subsidiaries of US MNCs in Europe is a potentially significant driver of change but so too must be the impact of host country pressures for change or stability, be they determined at firm level, system level or European level. That is, the country-of-origin effect has an impact on the competitive environment where subsidiaries are located but in addition the host environment may also have an impact on the practices of US MNCs. We seek to evaluate this argument in the next part of the article where we summarise recent developments originating in national business systems that may facilitate changes in the way firms manage IR. Here we concentrate on what our empirical material tells us about established patterns of IR management in subsidiaries of US MNCs. This will enable us to evaluate the extent to which the pressures for competitive isomorphism at the level of the system are ahead of those for institutional isomorphism at the level of the firm, a development that may indicate a pattern of internal divergence and variation in IR arrangements between and within European nations. 


\section{Empirical findings on firm-level IR systems in subsidiaries of US MNCs in the UK, Ireland and Germany}

Our empirical material examines established approaches to IR in these countries, particularly the profile of collective bargaining in national systems and subsidiaries of US MNCs and comments on institutional challenges to firm-based employment systems in relation to established approaches. Our reasoning for seeking these distinctions follows the arguments of Marginson and Sisson (2004: 12) who, like us, suggest that competitive isomorphism at the system level, that is a movement towards Americanisation, could at firm level lead to the break-up of collective bargaining and a weakening of trade unions as institutional stakeholders. More specifically, it is an open question as to whether the embryonic EBS can retain any systematic coherence when changes and developments in IR are institutionalised by individual firms at national level.

Table 1 presents the findings for the Irish and German subsidiary form, alongside the British data reported in more detail in last year's contribution.

In our previous analysis of the UK data (Clark and Almond, 2004), we argued that pressures captured under the 'shareholder value' label, alongside product market change and globalisation, had been more significant in provoking changes in the nature of the broader firm-level (or in some cases, subsidiary level) human resource (HR) management system than in the formal collective IR architecture within the subsidiaries. In other words, challenges to existing collective IR settlements had been limited, but this had not prevented a clear shift away from sophisticated paternalism and towards policies of an increasingly 'hard', 'performance-driven' flavour.

In adding Irish and German material to the analysis, we are able to supplement this picture, in order to gain a better perspective on the extent to which the relative stability of collective IR among the UK subsidiaries was a host country-specific finding, perhaps related to the comparative lack of constraints which pluralist arrangements in the UK present to global employers.

The Irish case is of interest both in terms of its similarities to the UK context and in certain significant differences. The centrally negotiated accords between the national 'social partners', which have characterised Irish IR for almost two decades, cover almost all unionised workers in the country, and influence wage setting among nonunion firms. The firm-level IR system is voluntaristic in nature, although the pluralist tradition tended historically to ensure that most incoming MNCs recognised unions.

Among our five Irish cases, however, there has been a substantial shift in the direction of non-union arrangements. Of the three firms whose initial investment in Ireland was before 1970, Pharmaco and Healthco followed the typical pattern of subscribing to collective bargaining, in line with government policy, although ITCo, which as can be seen from Table 1 is untypical in the long-lasting cohesion of its global non-union employment system did not. The two 1990s entrants, Compuco and Logistico, have both established largely non-union systems, although Logistico has been forced to concede recognition at the margins. Additionally, in recent years, as their investments in Ireland have grown, the corporate non-union preferences of companies such as Pharmaco and Healthco have been reflected in policy in their newer sites. In Healthco, all three of its more recently established Irish facilities operate on a nonunion basis, as does Pharmaco's newest facility. Both these cases (as well as the somewhat different case of Logistico) are examples of 'double-breasting' arrangements whereby multi-plant organisations recognise trade unions and engage in collective bargaining in some plants but not in others (Beaumont and Harris, 1992; Kochan 


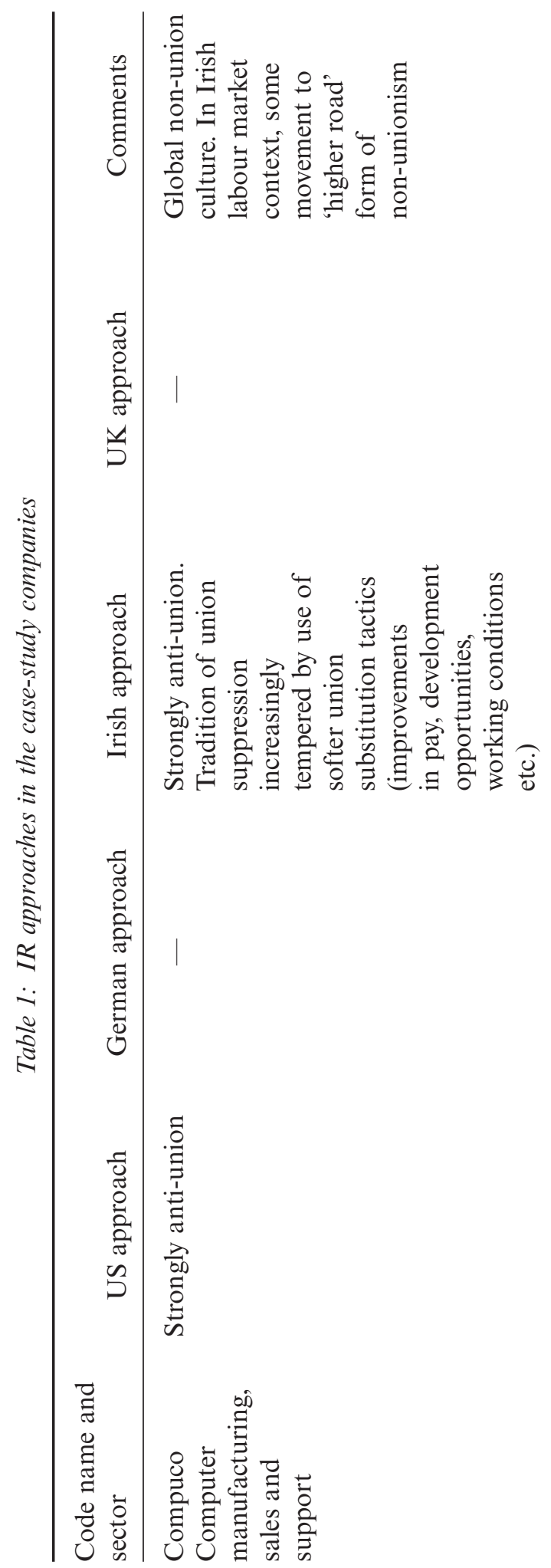




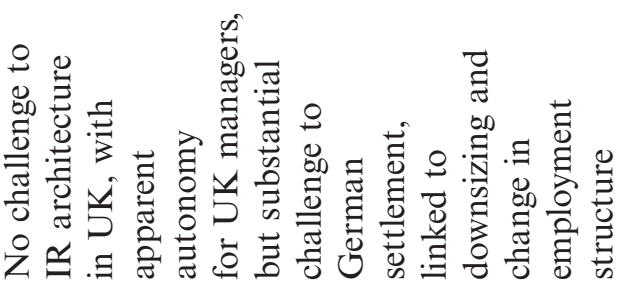

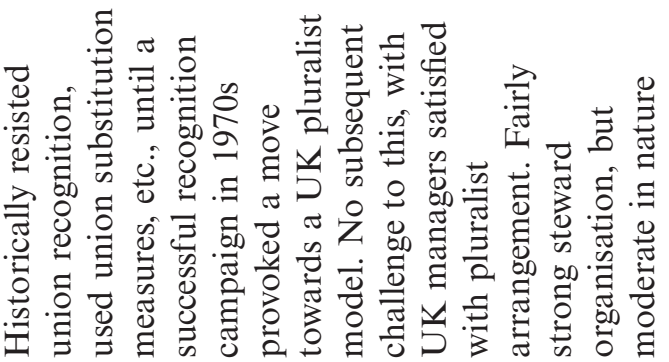

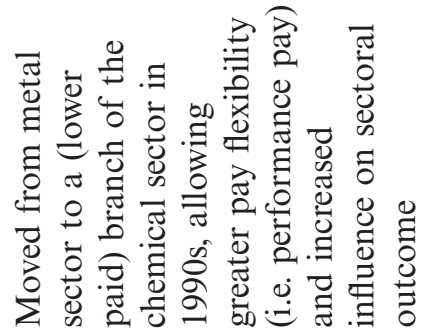

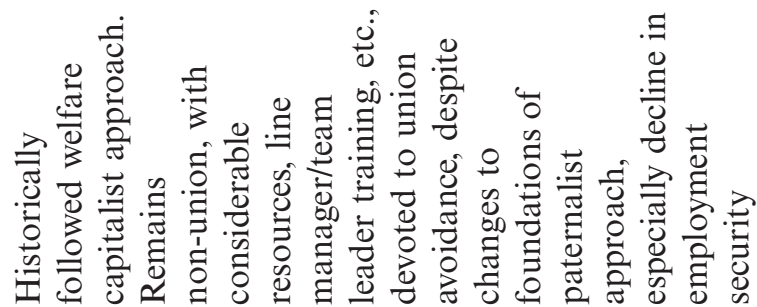

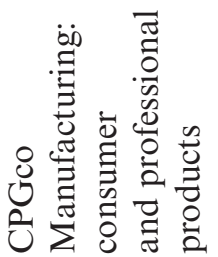




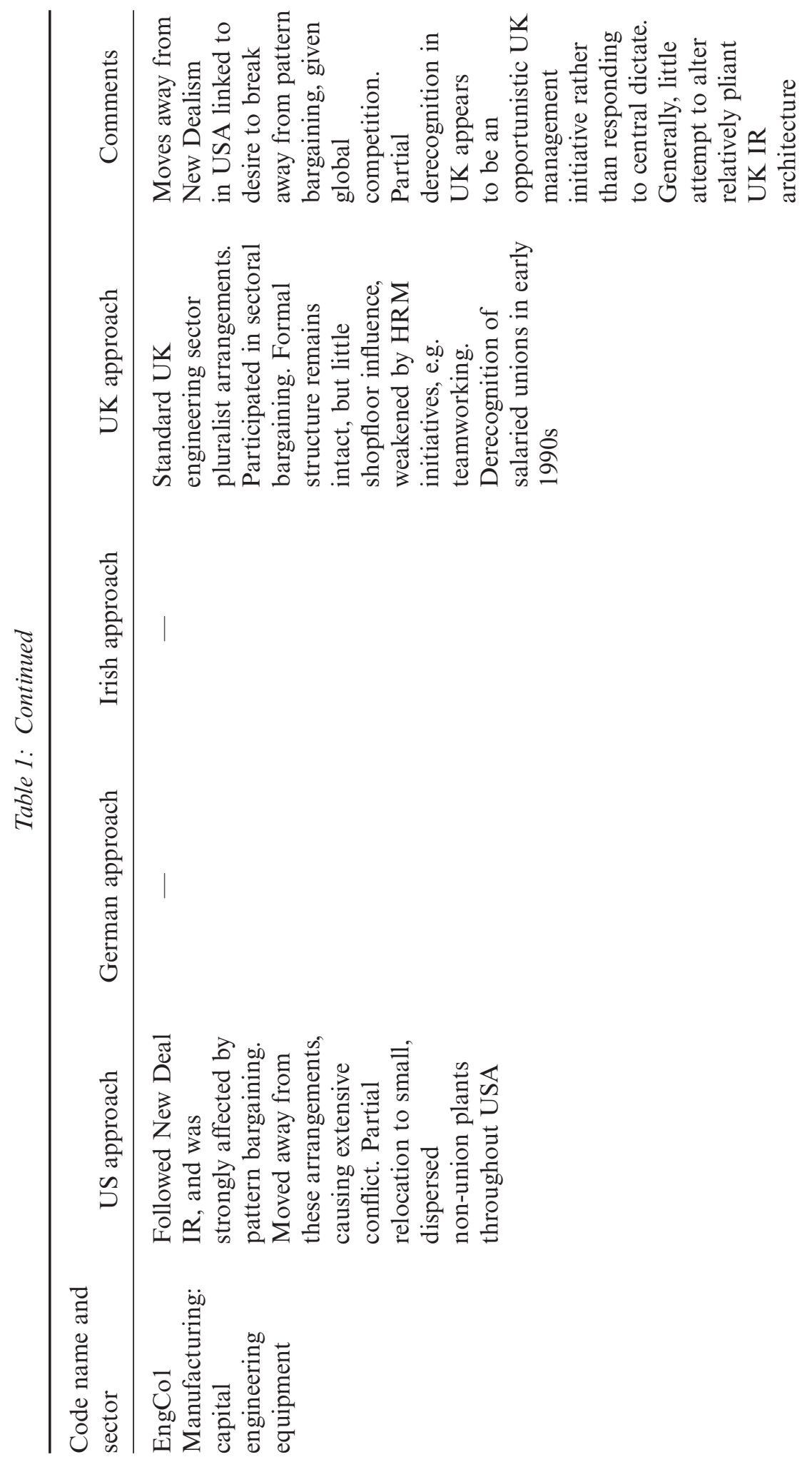



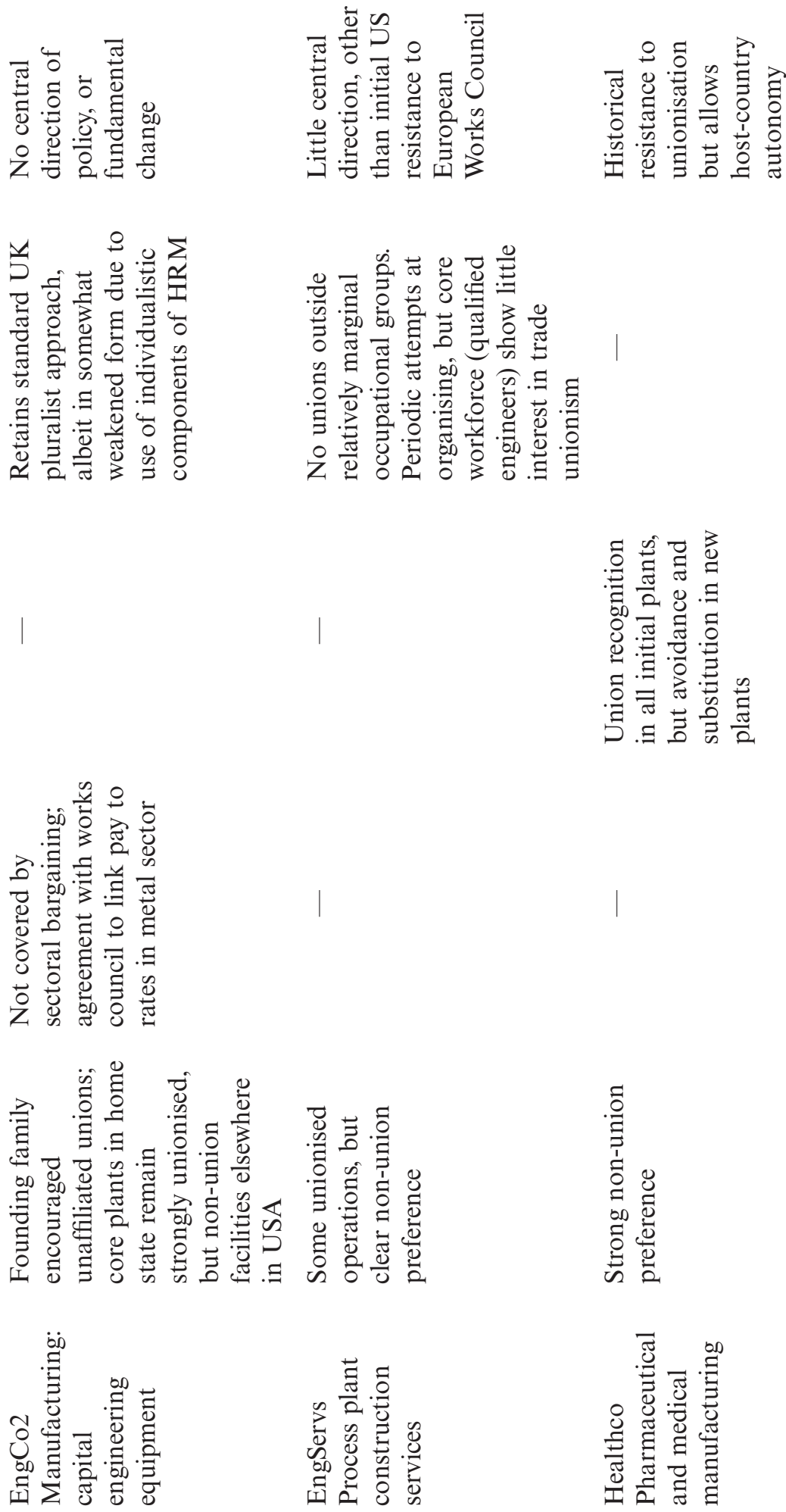


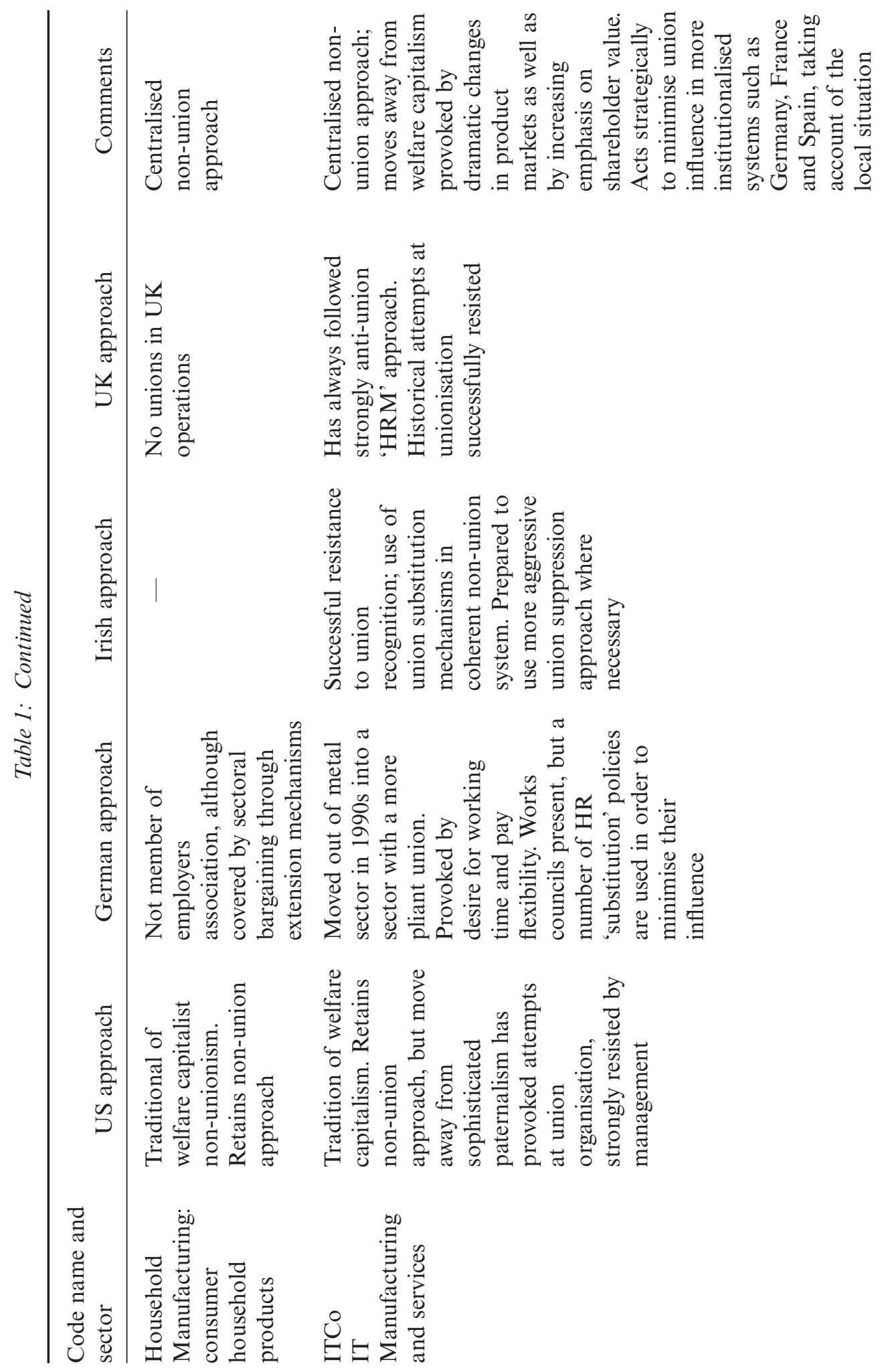

(C) Blackwell Publishing Ltd. 2005. 


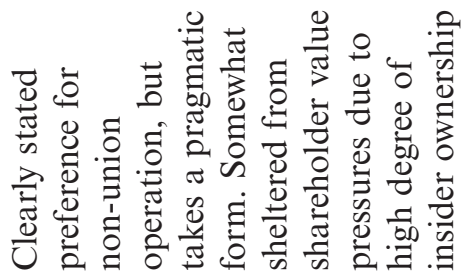
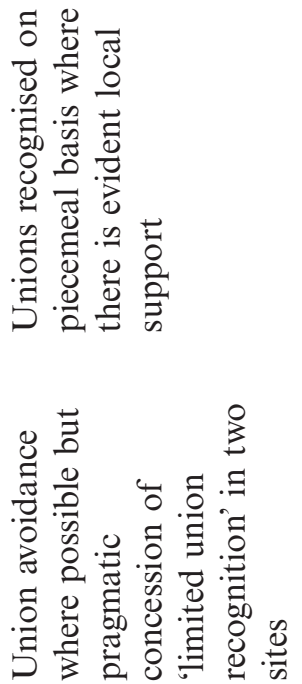

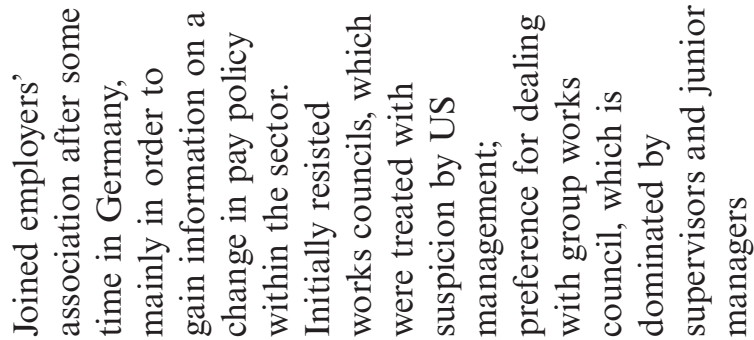
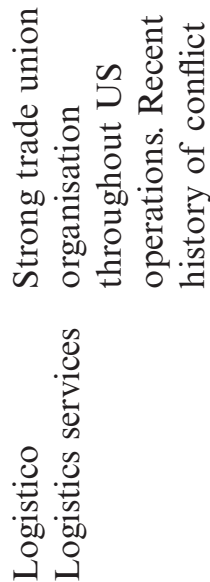


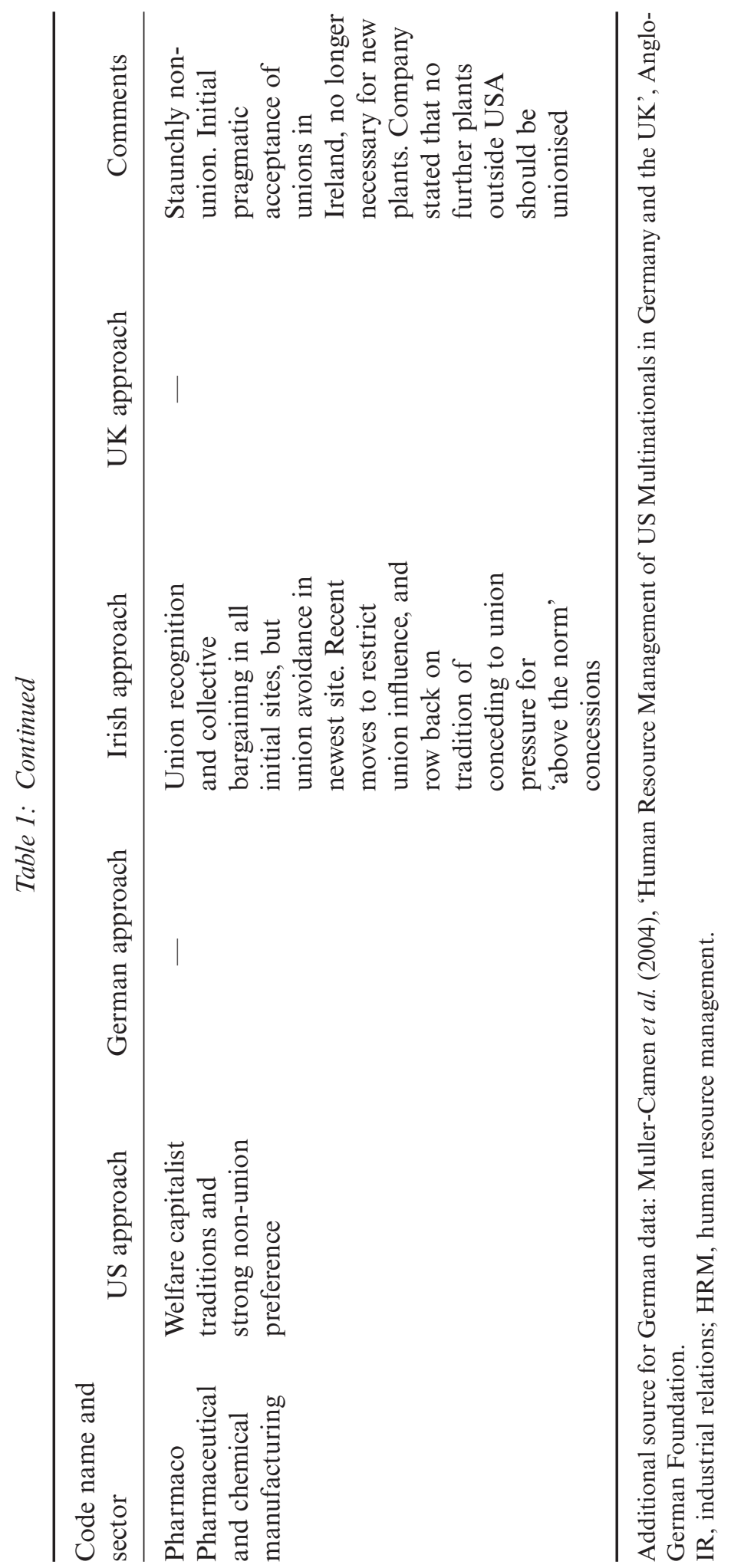


et al., 1986). There is, more generally, a progressive trend of increased union avoidance among MNCs in Ireland.

US MNCs have presented the most direct challenge to the existing IR system in Germany, with both the sectoral bargaining system, and, to a somewhat lesser extent, the system of codetermination being targets of policy change among some of our case study firms in the 1990s. While some US MNCs with relatively small German operations, such as EngCo2 and Household, have long avoided engagement with the sectoral system, in two of our other cases (ITCo and CPGco) the subsidiaries have taken the fairly radical step of changing their IR sector in order to secure a more favourable agreement. The direct driver in both these cases appears to have been flexibility, specifically the ability to relate a higher proportion of pay to performance and to avoid reductions in the length of the working week at the beginning of the 1990s. This new-found active intolerance of existing sectoral structures may well have been related to what the firms saw as necessary changes to HR management systems in the wake of restructuring, although here, as elsewhere, the erosion of the host's IR system may have played a part in allowing subsidiary managers to make changes in an opportunistic manner. Works councils do not appear to have been challenged in any direct manner. Our German respondents contend that their American counterparts mistrusted the concept of works councils, their sclerotic effect on German management decision making in particular was mentioned more than once by UK respondents in non-union companies. In addition to this some British managers felt that the German works council was sometimes used as an excuse by German managers for delaying the introduction of corporate policies with which they disagreed. In contrast to this German subsidiary managers were, on the whole, content with how their, fairly cooperative, works councils operated within their own firms.

In the face of relatively little legislative reform at state level, a recent trend in the German IR system has witnessed the greater use of concession bargaining and socalled employment 'pacts' between firms and unions in order to lower labour costs and facilitate greater flexibility (EIRR, 2003). A practice first highlighted by Hassel (1999) these pacts witness the decentralisation of collective bargaining from sector level to firm level to erode the established division of labour between collective bargaining and works councils that negotiate the implementation of bargaining agreements at plant level. Daimler-Chrysler, the department store chain Karstadt, the General Motors subsidiary Opel, Siemens and Volkswagen have each negotiated pay freezes and longer hours. Similarly, Debis (the Daimler Chrysler Services Group) recently negotiated collective agreements incorporating new forms of profit-related pay and Deutsche Telekom has recently negotiated the innovation of variable pay and negotiated pay agreements related to the performance of the firm. This development has led some commentators to argue that not only are the incomes of German workers being marketised the process of decentralisation reduces the significance of collective bargaining as pay increases and earnings are increasingly in the hands of companylevel works councils (Jackson et al., 2005).

\section{AMERICANISATION OR EUROPEANISATION? CHANGE, INNOVATION AND INTERNATIONALISATION IN EBSs}

A basic premise of much of the research on MNCs is that they are embedded within the institutions, associated practices and contemporary dynamics of their national business system. Following on from this, MNCs are likely to transfer aspects of 
nationality (both institutionally and culturally) to overseas operations. In the contemporary period an increasingly internationalised economic system appears to be dominated by the USA, a position that has since the 1950s encouraged other national business systems to 'import' American approaches to business in general and industrial relations specifically (Clark, 1999; Dunning, 1998; Ferner, 2003; Gilpin, 2000). For example, in the contemporary period current influences within the ABS such as shareholder value approaches to corporate structure and governance are often presented as a dynamic efficiency-bearing characteristic of the ABS and US MNCs (Edwards, 2004; Geppart, 2005; Grahl and Teague, 2004). However, there are questions over the extent to which shareholder value approaches can be effectively transmitted and diffused into EBSs either by US MNCs or by indigenous firms without substantive reform of EBSs (Gooderham et al., 1999; Jones and Bacon, 2004).

As the material in the previous part of the article demonstrates, in many cases firmlevel IR systems in subsidiaries of US MNCs may represent patterns of embeddedness that deter fully fledged movement to shareholder value approaches (see also Ferner et al., 2004). If, as this finding implies, the pressures for competitive isomorphism at the level of the business system are running ahead of pressures for institutional isomorphism at the level of the firm, it confirms continuing variation within national IR systems to suggest both converging and diverging trends within national business systems (see Katz and Darbishire, 2000). In the remainder of this article we summarise some recent competitive pressures that have resulted in legislative reform or sustained business pressures in the business systems under consideration.

\section{Competitiveness and productivity}

The American model of business and employment emphasises individualism, individual initiative, flexible unregulated labour markets and low taxation, particularly payroll taxes. In contrast to this the European model emphasises collectivism, regulated labour and product markets, higher taxation and a comparatively generous welfare state. The European model appears problematic to sclerotic, the Lisbon strategy is now associated with missed targets and a failure of political will whereas the American model continues to create employment and sustain higher levels of labour productivity and lower unit labour costs [see Table 2 and International Monetary Fund (IMF), 2005]. Although often cited this point is controversial; data for hourly productivity indicate that several European countries outperform the ABS, especially once the "new economy' [IT start-ups and dotcom boom are removed from long-term trends (Jacoby, 2005: 41; Nolan and O'Donnell, 2003: 497)]. The key difference between European employees and those in the ABS centres on the number of hours worked, a point noted by many 'no' voters in the EU Constitution referendum in France and the Netherlands. The controversial point about this revolves around whether or not preference for shorter working hours is a weakness or strength of continental European economies. Hence, the ABS appears more competitive and productive than European economies prompting American-dominated international institutions such as the IMF and Organisation for Economic Co-operation and Development (OECD) to argue that in order the achieve American-style living standards it is essential for European states (including the UK) to liberalise labour markets. For France this would result in a lower national minimum wage for young workers and an extension to the 35-hour working week, for Germany it would require a significant reduction in income tax and an equally significant reduction in unit labour costs. The American Chamber of Commerce in Germany reports that high costs and rigid labour market regulations

(C) Blackwell Publishing Ltd. 2005. 
are driving US manufacturers out of the country. A survey commissioned by AMCham found that while 40 per cent of US MNCs in the survey planned to increase investment in Germany this year, 25 per cent said that despite this their investment in labour-intensive production and administrative facilities such as call centres would be reduced and redirected further east to lower labour cost economies such as Poland and other Baltic states (AMCham, 2005). This development appears to challenge the previously accepted arguments that US MNCs prefer to avoid trade unions and collectively regulated state institutions but less so in the case of Germany. Therein the evidence suggests that many US MNCs were prepared to tradeoff higher labour costs associated with such institutions against higher levels of labour productivity that could generally be expected in the German business system (Cooke and Noble, 1998).

In the UK the pressures associated with competitiveness and productivity centre on the so-called burden of red tape and regulation. In particular, employer bodies have lobbied the European Commission for lighter regulation in relation to the recently introduced Information and Consultation Directive and the anti-competitive effects of ending the UK's opt-out from the upper hours limit in the working time directive, in respect of both directives the strongest opposition came from the manufacturing sector. In response to a British delegation that included the British Chamber of Commerce, the Federation of Small Businesses and the Institute of Directors, Gunter Verheugen, the EU competition commissioner stated that each new European law, particularly employment regulations, would be judged on how they affected SMEs (Financial Times, 2004). Despite these arguments the evidence gathered in the Department of Trade and Industry (DTI)'s own report UK Competitiveness: Moving to the Next Stage (DTI, 2003) suggests that the UK has the lowest rate of labour and product market regulation in the OECD area and one of the highest levels of labour force utilisation in the OECD. In effect the report - written in the main by Michael Portersuggests that the UK is more Americanised (more deregulated) than other European economies. As a result of this the UK is less capable of competing effectively in the knowledge economy because of weaknesses in British management, national training initiatives and role of the government in remedying these defects.

In contrast to the position of Germany and the UK, Ireland has come from a position where it lagged significantly behind the UK, Western Europe and the USA on all indices of economic development [gross domestic product (GDP), gross national product (GNP) per capita, productivity, living standards, etc.] to a situation where, over the past decade, it has reached or passed all of these, except the USA. One of the major reasons for this convergence is Ireland's export performance, particularly in certain high-technology sectors. Because these sectors are mostly dominated by multinational subsidiaries, and because the USA is the major source of FDI, it is widely accepted that US MNCs have been a major driver of economic performance, including sustained productivity growth.

Independent evaluations of productivity changes in Ireland indicate a picture of steady and more recently spectacular growth. For example, Cassidy (2004) found that over the period 1961-2002, real GDP growth in Ireland averaged 4.75 per cent per annum (p.a.) compared with 3 per cent in the EU and 3.5 per cent in the USA. We find a similar picture in regard to labour productivity ${ }^{1}$ (GNP per worker), which

\footnotetext{
${ }^{1}$ Numerous commentators have suggested that GNP is a more valid measure of economic performance in Ireland because it excludes the large profit repatriation of foreign-owned MNCs. We should also caution that productivity levels in Ireland are likely to be artificially inflated by the transfer pricing activities of these MNCs.
} 
Table 2: Gross domestic product (GDP) per capita [in purchasing power standard (PPS) ], US $=100$

\begin{tabular}{lcc}
\hline & \multicolumn{2}{c}{ GDP per capita } \\
\cline { 2 - 3 } & 1970 & 2000 \\
\hline Germany & 78.7 & 74.2 \\
Ireland & 41.9 & 81.7 \\
Spain & 49.8 & 57.5 \\
UK & 70.8 & 70.2 \\
EU-15 & 69 & 70.3 \\
USA & 100 & 100 \\
\hline
\end{tabular}

Source: Sapir et al. (2004).

increased at an average rate of 2.75 per cent p.a. over the period, similar to the EU average. However, the rate of increase since 1980 was 2.5 per cent p.a. compared with 1.75 per cent in the EU. Largely due to strong growth during the 1990s, labour productivity in Ireland has risen dramatically relative to the EU and the USA (see Table 2).

Much of the growth in Irish productivity is attributed to foreign direct investment (FDI), particularly US FDI. In assessing the Irish experience in regard to productivity growth, MIT economist Paul Krugman (1997: 43) comments:

To some extent, however, Ireland's favourable productivity performance is surely a result of its success in becoming the premier European host to inward foreign direct investment. [US FDI is 50 per cent higher per capita than in the UK, six times as high as in France or Germany.]

Ireland's reliance on FDI is well documented and the USA is by far the largest source, accounting for just under half of all foreign-owned firms. OECD (2000) data indicate that US FDI into Ireland increased by a factor of five over the period 1990-98, while the Economist (1997) found that FDI stock from US firms amounted to $\$ 3,000$ per head in Ireland, compared with $\$ 2,000$ per head in the UK, \$500 in Germany and $\$ 200$ in Spain. The great bulk of this investment is located in a small number of hightechnology sectors, notably electronics, pharmaceuticals and healthcare, software and internationally traded services. These MNCs are almost exclusively export-orientated (95 per cent in US plants). Looking specifically at US FDI, Barry (1999) found that US plants in Ireland tend to be much larger, five times more productive, and eight times more profitable. Not surprisingly, the FDI sector has higher skill levels than indigenous firms (cf. Barry, 1999; 2002).

\section{Shareholder value and organisational capabilities}

In our last year's review we stated that 'the emergence of shareholder value and more determined short-termism within British subsidiaries of US MNCs is only as significant as the existing pressures on indigenous firms embedded within the British business system' (Clark and Almond, 2004). In contrast to this the Irish data are 
inconclusive on this issue. What we do find though, is a pattern in increasing corporate control over HR and other aspects of subsidiary-level management. Much of this entailed an increased level of performance measurement, so that subsidiaries had to regularly supply information on a wide range of metrics, most focused on financial and operational performance and allowing a greater degree of comparison of performance across subsidiaries. The HR agenda is increasingly focused on performance improvement, using a series of metrics to evaluate and push this agenda. ITCo was probably the most extreme. Many of the HR policies were focused on encouraging and developing a 'high performance orientation', aided by the use of a range of performance metrics applied at individual, team, department and establishment level. The company's Irish operations represent quite pressurised work contexts with high expectations and goals set at various levels down to individual employees.

On a related theme, it would appear that changes in the structure of corporations have focused on lessening dependence on particular subsidiaries and increasing market competition within the corporation. This would appear to have altered the IR power balance, a development particularly evident in regard to Pharmaco. Here Pharmaco 1 (its major manufacturing plant), which had for many years occupied a critical position in the corporation's production chain, has now seen this change:

In 1972 Pharmaco \#1 made 40 per cent of the active ingredient worldwide. This often led to IR trouble, strikes and pay claims. They [unions/employees] could shut you down. It also led to the high pay and benefits. But since the acquisitions there are now 16 [manufacturing] plants. I have talked to them [union representatives] about 'relative attractiveness'. There are guys sitting down in New York and deciding where to put new investment. [They] now have 16 choices. The days of IR trouble are disappearing.

Competition is more severe internally than externally [Irish team, Interview notes].

In summary, there are three important developments taking place which may well be driven by more short-termist and shareholder value pressures. First, increasingly levels of centralised (corporate) control, as manifested in increased reporting requirements/use of metrics to evaluate subsidiary performance and compare with other subsidiaries (in Ireland it would seem that 'moving up the value chain' is a doubleedged sword in regard to autonomy ... as a site moves up it comes under greater corporate surveillance and strictures). Second, structural changes/reorganisation to lessen dependence on single sites and increase internal competition between sites for new business. Third, increasing emphasis on continuous performance improvements (again in regard to particular metrics, and incorporating global performance management programmes).

In contrast to these firm-level innovations which may indicate more institutional isomorphism in the Irish business system in the German business system recent developments as we indicate above are more evident at the system level and challenge existing patterns of corporate governance. Firstly, the German code of good practice for corporate governance Dax, aims to develop greater financial transparency in large German corporations, better information for capital and financial market actors and a strengthening of shareholder rights. As a principle to govern corporate investments shareholder value has been widely discussed by academics and practitioner bodies and as a result many corporations quoted on the German stock market have changed their reporting and accounting principles. This has put strains on the traditional stakeholder orientation of German firms. However, the shorter-term orientation of contemporary German managers and a clearer concentration on shareholder interests, for example, cost reduction-inspired lay-offs is still perceived as 'American' in Germany (Business Week, 2004; FAZ, 2005). A consequence of the shifting balance 
between stakeholder and shareholder interests at corporate level has been an explicit attack on codetermination (particularly corporate-level union representation on the supervisory board) by employer associations and some economists who suggest that German corporations need to follow the lead of US firms in Germany who are less inclined to remain located in the German business system when there are clear cost advantages to relocation in lower-cost states within and beyond the EU.

\section{DISCUSSION AND CONCLUSION}

A review of this type blends empirical observation, commentary on recent institutional and legislative developments and theoretical argument to provide a forum for further development of themes, peer criticism and academic debate. Our major empirical material, while limited to subsidiaries of US MNCs, is informative to our general arguments because if one is looking for the impact of Americanisation one might expect to find its impact in subsidiaries of US MNCs. The diffusion of US MNCs into Europe has provided a greater awareness of diversity in organisational forms, principles of corporate governance and associated IR practices. This diversity of practice illustrates variation which is the basis of the comparative institutional approach wherein different economic, political and social advantages lead to multiple patterns of viability and leverage in the global economy. The diffusion of US MNCs tests the resilience of indigenous organisational forms, particularly in continental Europe, in the face of apparently unstoppable convergence around one template for enterprise-level best practice or global efficiency at system level.

The historical and contemporary evidence on the diffusion of 'American' business and IR practice reveals a mixture of innovation and embedded patterns of local isomorphism that has resulted in a pattern of incremental adaptation and hybridisation and continued diversity of national business systems (see Djelic, 1998; Ferner et al., 2004; Gooderham et al., 1999; Mayer and Whittington, 2004). However, if as our empirical material on subsidiaries of US MNCs suggests they are not at the forefront of a movement to more Americanised methods of management where are the pressures for Americanisation coming from? Like some of the contributors to last year's review we have to follow the arguments of established economic sociologists (see Smelser and Swedberg, 1994; Streeck, 1997) who argue that organisational actorsstates, the European Parliament and the European Commission, indigenous firms, labour unions and financial institutions - while they react in a variety of ways to globalisation that reflect the embeddedness of national patterns of institutional organisation, may, over time, reposition themselves. That is, in the face of either sectoral developments (Royle, 2004) or emergent system pressures (Grahl and Teague, 2004) a pattern of regime fragmentation may be emerging across the EU whereby member states may encourage institutional change beyond that formulated at EU level. It follows from this that the sources of Americanisation are manifold in the EU; subsidiaries of US MNCs may diffuse practices associated with the ABS or more likely diffuse the rhetoric of contemporary business strategies into general usage, sectors dominated by US MNCs such as fast food are more likely to see substantive take-up of lower road strategies. Similarly in Germany indigenous firms in the SME or Mittelstand sector are likely to deploy American-inspired approaches to people management that are unavailable to larger German firms. At the level of the state nations such as Ireland and Spain have for some time viewed MNCs as partners in economic

(C) Blackwell Publishing Ltd. 2005. 
development and pursued permissive export-led strategies towards FDI. Both countries have downplayed ownership issues to pursue full integration in the global economy and EU in exchange for economic growth and job creation. In many respects Ireland is more Americanised than the UK, particularly in the weakness of its union recognition legislation, but our evidence also points to a high level of variation in the HR approaches used. For example, only one of the case firms studied (ITCo) seems to 'toe the corporate line' in almost all aspects of HR. All of the other cases employed HR approaches which in many regards accommodated their Irish host environment. However, in all of the cases, certain aspects of the US business system were evident. The US influence was most evident in the information and communications technology firms, specifically in the performance management orientation, individualist emphasis and eschewing of collective employee representation to the greatest degree possible. In the pharmaceuticals and healthcare firms, the trend of union avoidance in new plants, mentioned above, also reflects a strong country-of-origin influence which is facilitated by the growing number of non-union firms, both indigenous and foreign owned, in Ireland. Other areas where corporate influence seemed to pertain include the issue of performance management, safety and quality management. On the latter two issues, it is clear that sectoral factors are particularly important. In the pharmaceutical and healthcare sectors, it is standard practice for auditors from Corporate HQ to periodically visit the Irish subsidiaries to monitor the systems used. This process of regular monitoring by HQ relates to the imperative to obtain/retain regulatory approval. However, in other aspects of HR practice, we found little evidence of extensive corporate imposition of $\mathrm{HR}$ policies, procedures or practices in either Healthco or Pharmaco.

Our investigations also indicate a time of significant change for US subsidiaries in Ireland. In particular, we found a consensus among management, employees and trade unions in all of the case firms that in order for the Irish operations to remain viable, they must move up their corporation's 'value chain', through engaging in higher valueadded activities, and concurrently improve their competitiveness (in terms of productivity, etc.). Ultimately, this means raising their profile at the corporate level and convincing top management there of Ireland's capacity to take on 'higher order' responsibilities (i.e. more complex, higher margin products). The Healthco case illustrates this position: the strategy of the Irish management team is twofold: (i) impress HQ by performing well in relation to its current responsibilities and sending out Irish managers to Corporate HQ to network and (ii) convince corporate management as to Ireland's capacity to take on new and more challenging product lines. To date the Irish company has been remarkably successful with this strategy. The prospects for the other MNCs in Ireland remain to be seen. The other key trend emerging in all of the case firms is that of increasing corporate control-although this is probably least discernible in ITCo, given its tradition of conforming to corporate policy in almost all aspects of HR practice. Management respondents in Pharmaco, Healthco and Compuco all spoke extensively about the progressive trend increasing corporate involvement in the management of the Irish operations. While we are clearly in the realm of speculation, it is our opinion that many Irish subsidiaries of US corporations which have experienced many years of considerable HR autonomy are entering a phase whereby they will be increasingly subjected to greater corporate control.

In conclusion, we can make four points. First, if Europe is about economic performance and the control of multinationals it is about the balance between economic efficiency and industrial democracy and the balance between these is entangled in the 
wants and aspirations of a previous era (Jones, 2004). As Jones states there is no easy way to make the argument, developments in enterprise strategies appear to suggest the logic of renegotiating pre-existing accommodations at system level, that is the balance in national business systems in Europe is leaning towards economic efficiency rather than industrial democracy associated with socially embedded market institutions within member states in the EBS. Second, if the first conclusion is true, what are these enterprise developments and where do the sources of pressure come from? Simplistically, one would expect them to come from the efficiency-spillover effects of US MNCs because the enterprise developments - downsize and distribute models of corporate governance, shareholder value or 'Anglo-American' methods are in large measure associated with developments in the ABS. However, our empirical material suggests that beyond stereotypical sectors such as fast-food US MNCs in Europe have relatively permissive approaches to IR that in many cases accommodate host country factors, particularly in Germany. Alternatively, as the editors argued last year, the pressures are evident at the system level where more liberal permissive systems such as Ireland and the UK lobby to maintain this liberalism and in contrast to this German employers in a more coordinated and defensive system seek some form of pathway adjustment to accommodate American FDI and facilitate contemporary enterprise strategies in subsidiaries of US MNCs and indigenous firms. As we argue, the renegotiation of existing accommodations is more system driven than US MNC driven. Third, efficiency and industrial democracy are issues of distribution, here employment rights are factored against their associated administrative and transaction costs which reduce potential returns to investors. Across the EU the issue centres on the cost of industrial democracy - the (so-called) burden of red tape - the costs of enforcing and regulating employment rights and the cost of servicing such rights to firms (set-up costs and overhead costs in personnel) and the consumer (higher prices and the tax burden). The central argument we make here is what might be termed the '1992 election argument' - we all like the idea of workers in the EU being well treated, etc. but like the idea of paying for it less so. By this we mean that the benefits to workers of socially embedded market institutions such as IR systems cost money, for example, in terms of regulation and enforcement and the costs associated with enacting benefits such as maternity leave, reductions in employer flexibility imposed by shorter qualification tenures for unfair dismissal and restrictions on working time. Most right-minded individuals can in the abstract see the benefits to civil society of such practices; however, when faced with the prospect of paying for them indirectly via higher taxation or higher consumer prices the position becomes more complicated. Employers rightly or wrongly complain about the costs of regulation which are in fact paid by consumers directly and in some cases via redundancy as operations are moved to lower-cost economies. It follows from this that much of the debate about regulation and the utility of embedded social market institutions has developed within the EU, for example, in the distinctly British view of the EU Constitution and the French and Dutch view that it is too Anglo-American. Hence, the internal challenge to the EU model of employment rights operates in addition to and independently of the challenge and pressures that might be associated with the direct and spillover effects of US MNCs. Finally, the arguments and primary empirical evidence supported by secondary empirical references in this article suggest that Americanisation and Europeanisation are both moving targets at the level of national business systems. Subsidiaries of US MNCs export Americanness but accommodate Europeanness in varying degrees as informed by the permissiveness or otherwise of the host business system.

(C) Blackwell Publishing Ltd. 2005. 
The EU expresses a coordinated union-wide approach to IR; however, the EU loosely manages a continent, not a state, therefore member business systems retain their national characteristics wherein reform, accommodation and permissiveness towards EU directives, US MNCs and Americanisation is managed.

\section{References}

American Chamber of Commerce in Germany (2005), Perspectiven Zum Standort Deutschland, Berlin, Germany, March.

Barry, F. (1999), FDI and Industrial Structure in Ireland, Spain, Portugal and the UK: Some Preliminary Results, unpublished paper presented to Annual Conference on the European Economy, ISEG, Lisbon, 14 December.

Barry, F. (2002), FDI and the Host Economy: A Case Study of Ireland, unpublished paper presented at Department of Management, National University of Ireland, Galway, 8 November.

Beaumont, P. B. and R. I. D. Harris (1992), “"Double-breasted” Recognition Agreements in Britain', International Journal of Human Resource Management, 3, 2, 267-283.

Business Week (2004), 'Europe's Old Way's Die Fast', 17 May 2004.

Cassidy, M. (2004), 'Productivity in Ireland: Trends and Issues', Quarterly Bulletin, Irish Central Bank, Spring, 83-104.

Clark, I. (1999), 'Institutional Stability in Industrial Relations and Management Practice: The Influence of the Anglo-American Council for Productivity, 1948-1952', Business History, 41, 3, 64-93.

Clark, I. and P. Almond (2004), 'Dynamism and Embeddedness: Towards a Lower Road? British Subsidiaries of American Multinationals', Industrial Relations Journal, 35, 6, 536557.

Coller, X. and P. Marginson (1998), 'Transnational Management Influence over Changing Employment Practice: Surveying Cases from the Food Industry', Industrial Relations Journal, 29, 1, 4-17.

Cooke, W. and D. Noble (1998), 'Industrial Relations Systems and US Foreign Direct Investment Abroad', British Journal of Industrial Relations, 36, 4, 581-609.

Department of Trade and Industry (2003), UK Competitiveness: Moving to the Next Stage (London, DTI).

DiMaggio, P. and W. Powell (1983), 'The Iron Cage Revisited: Institutional Isomorphism and Collective Rationality in Organizational Fields', American Sociological Review, 48, 161-173.

Djelic, M. (1998), Exporting the American Model: The Post-war Transformation of European Business (Oxford, Oxford University Press).

Dunning, J. (1998), American Investment in British Manufacturing Industry: Revised and Updated Edition of the 1958 Original (London, Routledge).

Economist (1997), 'Green is Good: Advantages of Ireland as a Host for F.D.I.', 17 May, 343, 8017, 21-24.

Edwards, T. (2004), 'Corporate Governance, Industrial Relations and Trends in Company-level Restructuring in Europe: Convergence Towards Anglo-American Multinationals', Industrial Relations Journal, 35, 6, 518-536.

EIRR (2003), 'Germany: Collective Bargaining in 2002', European Industrial Relations Review, 351, 21-25.

FAZ (2005), 'Die Zeit der Gemutlickeit für die Deutschland AG ist zu Ende' [The Time of Cosiness for German Firms is Over], 8 March 2005.

Ferner, A. (2003), 'Foreign Multinationals and Industrial Relations Innovation in Britain', in P. Edwards (ed.), Industrial Relations in Britain, 3rd edn (Oxford, Blackwell) pp. 81105. 
Ferner, A., P. Almond, I. Clark, T. Colling, T. Edwards, L. Holden and M. Muller (2004), 'The Dynamics of Central Control and Subsidiary Autonomy in the Management of Human Resources: Case Study Evidence from US Multinationals in the UK', Organization Studies, 25, 3, 363-393.

Financial Times (2004), 'Promise to Reduce Burden of European Red Tape', 9 September 2004.

Geppart, M. (2005), 'Competence Development and Learning in British and German Subsidiaries of MNCs: Why and How National Institutions Still Matter', Personnel Review, 34, 2, $155-178$.

Gilpin, R. (2000), The Challenge of Global Capitalism: The World Economy in the 21st Century (Princeton, NJ, Princeton University Press).

Gooderham, P., O. Nordhaug and K. Ringdal (1999), 'The Institutional Determinants of Organizational Practices: HRM in European Firms', Administrative Science Quarterly, 44, 2, 507-531.

Gospel, H. and A. Pendleton (2003), 'Finance, Corporate Governance and the Management of Labour: A Conceptual and Comparative Analysis', British Journal of Industrial Relations, 41, 3, 557-582.

Grahl, J. and P. Teague (2004), 'The German Model in Danger', Industrial Relations Journal, 36, 5, 557-588.

Hall, P. and D. Soskice (2001), 'An Introduction to the Varieties of Capitalism', in P. Hall and D. Soskice (eds), Varieties of Capitalism: The Institutional Foundations of Comparative Advantage (Oxford, Oxford University Press) pp. 1-71.

Hassel, A. (1999), 'The Erosion of the German System of Industrial Relations', British Journal of Industrial Relations, 37, 3, 483-505.

Hutton, W. (2002), The World We're in (London, Little, Brown).

International Monetary Fund (2005), Economic Outlook (draft and press release) IMF, Washington DC, March.

Jackson, G., M. Hopner and A. Kurdelbusch (2005), 'Corporate Governance and Employees in Germany: Changing Linkages, Complementarities and Tensions', cited in H. Gospel and A. Pendleton (2003), 'Finance, Corporate Governance and the Management of Labour: A Conceptual and Comparative Analysis', British Journal of Industrial Relations, 41, 3, 557582.

Jacoby, S. (2000), 'Corporate Governance in Comparative Perspective: Prospects for Convergence', Comparative Labour Law and Policy Journal, 22, 5-32.

Jacoby, S. (2005), 'Corporate Governance and Employees in the United States', in H. Gospel and A. Pendleton (eds), Corporate Governance and Labour Managemen: An International Comparison (Oxford, Oxford University Press) pp. 33-59.

Jones, E. (2004), 'The Politics of Europe 2003: Differences and Disagreements', Industrial Relations Journal, 35, 6, 483-499.

Jones, E. and N. Bacon (2004), 'Editorial: The New Europe', Industrial Relations Journal, 36, $6,480-483$.

Katz, H. and O. Darbishire (2000), Converging Divergences: Worldwide Changes in Employment Systems (Ithaca, NY, ILR).

Kochan, T. A., H. C. Katz and R. B. McKersie (1986), The Transformation of American Industrial Relations (New York, Basic Books).

Krugman, P. R. (1997), 'Good News for Ireland: A Geographical Perspective’, in A. W. Gray (ed.), International Perspectives on the Irish Economy (Dublin, Indecon Economic Consultants).

Lane, C. (2003), Changes in Corporate Governance of German Corporations: Convergence to the Anglo-American Model? Centre for Business Research, Working Paper No. 259, Cambridge University.

Marginson, P. and K. Sisson (2004), European Integration and Industrial Relations: Multi-level Governance in the Making (Oxford, Oxford University Press). 
Mayer, M. and R. Whittington (2004), 'Economics, Politics and Nations: Resistance to the Multidivisional Form in France, Germany and the United Kingdom, 1983-1993', Journal of Management Studies, 41, 7, 1057-1082.

Milne, C. (2005), 'Daimler to Face Criticism at AGM', Financial Times, 6 April 2005, p. 29.

Muller-Camen, M., A. Tempel, P. Almond, T. Edwards, A. Ferner, R. Peter and H. Wachter (2004), HRM in US Multinationals in the UK and Germany (London, Anglo-German Foundation).

Nolan, P. and K. O'Donnell (2004), 'Industrial Relations, Performance and HRM', cited in P. Edwards, 'Corporate Governance, Industrial Relations and Trends in Company-level Restructuring in Europe: Convergence Towards Anglo-American Multinationals', Industrial Relations Journal, 35, 6, 518-536.

OECD (2000), International Direct Investment Statistical Yearbook (Paris, OECD).

O'Sullivan, M. (2000), Contests for Corporate Control and Economic Performance in the United States and Germany (Oxford, Oxford University Press).

Royle, T. (2004), 'Employment Practices of Multinationals in the Spanish and German Quickfood Sectors: Low Road Convergence?', European Journal of Industrial Relations, 10, 1, 5171.

Sapir, A., P. Aghion, G. Bertola, M. Hellwig, J.-P. Ferry, K. Dariusz, J. Vinals and H. Wallace (2004), An Agenda for a Growing Europe: The Sapir Report (Oxford, Oxford University Press).

Smelser, N. and R. Swedberg (1994), 'The Sociological Perspective on the Economy', in N. Smelser and R. Swedberg (eds), The Handbook of Economic Sociology (Princeton, NJ, Princeton University Press) pp. 1-40.

Streeck, W. (1997), 'German Capitalism: Does it Exist? Can it Survive?', in C. Crouch and W. Streeck (eds), The Political Economy of Modern Capitalism: Mapping Convergence and Diversity (London, Sage) pp. 33-55.

Tucker, S. (2005), 'Caterpillar Caught in Activist Crossfire', Financial Times, 4 April 2005, p. 25.

Vedrine, H. and D. Moisi (2001), France in the Age of Globalization (Washington DC, Brookings Institute).

Whitley, R. (2000), Divergent Capitalism: The Social Structuring and Change of Business Systems (Oxford, Oxford University Press). 